\title{
Relationship of Instructional Leadership, Organizational Climate and Teacher's Commitment to Job Satisfaction
}

\author{
Maya Elizah Harahap *, Ahmad Suriansyah, Suhaimi \\ Master Program of Education Management, Universitas Lambung Mangkurat, Banjarmasin 70123 \\ Indonesia
}

Article history:

Submission November 2019

Revised June 2020

Accepted June 2020

*Corresponding author:

E-mail:

mayaharahap23@yahoo.com

\begin{abstract}
Teachers are the most important and dominant factor in education because they are educational servants who have a direct relationship with the students and also members of the school organization. Thus, the school principal`s role, conducive school environment, and teacher commitment should be maintained so that the job satisfaction of the teacher is fulfilled. This study aims to analyze the role of a principal, concerning leadership style, the provision of a conducive school environment, and ensuring teachers' commitment, to attain learning satisfaction in public elementary schools. This research was conducted in Tapin Utara District, with a sample of Ninety elementary school teachers selected at random. The analytical method used is the analysis method using the IBM SPSS 20 . the results show that there is a direct and indirect relationship between instructional leadership, organizational climate, teacher commitment, and job satisfaction. the principal's leadership is the basis for the job satisfaction achievement for both teachers and staff in the organization, directly and through the organizational climate created and the commitment of each teacher.
\end{abstract}

Keywords: Instructional, leadership, organizational climate, teacher's commitment, job satisfaction

\section{Introduction}

Schools are educational organizations for achieving national education goals, and their success is dependent on human resources, including the principal, teachers, students, administrative staff, and other education personnel. Asniwati (2015) reported the characteristics of quality in the school include the concept of educational leadership, goals, professional community development, and the creation of a positively influencing atmosphere for imparting knowledge.

The teacher is a very dominant and most important factor in education, based on the characteristics of being servants for students and personnel of the school organization. Moreover, the role of a good leader or principal is the provision of a conducive school environment, and to maintain the commitment of teachers to work needs, in an attempt to ensure the fulfillment of job satisfaction.

Principals and teachers will always conduct communication and interactions in school. The principal, teachers, and employees (school personnel) must be in an appropriate or supportive environment (conducive) to complete all tasks properly. Therefore, a conducive climate will provide comfort and freedom feeling for their duties or work (Wahyuningrum, 2015). Thus, enhanced accuracy in performing their specific teaching functions leads to better-guaranteed creation and maintenance of reliability, as well as the readiness of human development. 
According to Mohtar (2019), teacher job satisfaction was described as a collection of positive attitudes regarding the healthy adjustment of employees, towards various conditions and work situations, including wages, social, physical, and psychological circumstances. Luthans stated the existence of several factors that affect job satisfaction, which include: the nature of the designated task, compensation plan, promotion, relationship with colleagues, supervision, and the work environment (Indrasari, 2017). Hence, job satisfaction is always associated with an employees' response towards the gains from the work organization, based on the task completed.

According to Indrasari (2017) reported that employees work in units and also face a variety of situations concerned with colleague relationships, supervisory policies, benefits received, and promotion opportunities. Also, most management parties believe that job satisfaction affects labor behavior, work commitment, productivity, absenteeism, and turnover. Furthermore, job satisfaction is considered as an important predictor in achieving individual welfare. Hadiyanto (2016) reported that the school environment possesses the ability to cause changes in the behavior of children and teachers, ultimately influencing their work performance. Also, the principal plays an important role in creating a conducive working environment, subsequently leading to teacher job satisfaction.

A principal is the leader of an educational organization, and also one of the key determinants of the schools' success towards achieving its goals. According to Sagala (2013), This achievement is predominantly controlled by the reliability of the management concerned, which is in turn strongly influenced by the leadership capacity of the principal.

Principals as school leaders have high and full responsibilities in an effort the commitment building, working with all components of the school and to achieve school success (Amran, 2015). Therefore, the success obtained is reflected in the comfort of school residents to carry out work or study, improvement in the performance of employees or teachers and other staff, and the satisfaction of external customers affiliated with this case. These include the parents feeling of satisfaction with the Childs' success.

According to Ariyani (2017) as an education leader, the School Principal has demanded the number and responsibilities of the task. The School Principal needs to apply the appropriate leadership style, optimally. The need for the ability to influence others, by means to bring out the best personal creativity within the school development process.

Every individual has different values, principles, and motives, and all these elements interact and influence one another. According to Usman (2014), this tends to further shape the atmosphere or climate of the organization, by exhibiting visible (physical), or invisible (emotional) characteristics. Furthermore, organizational climate is the working atmosphere experienced by employees, which ought to possess a sense of security, adequate lighting, facilities, and infrastructure.

Organizational climate is a concept that describes the quality of the internal environment that is capable of effect the behavior of its members in performing designated tasks. According to Pace and Faulos (2006) this concept is important in schools because of the intrinsic ability to bridge the practices of human resource management and productivity.

A conducive school organization climate required the leaders who understand interpersonal diversity between school environments. This opinion was made clear by Mataputun (2018) that the principal had sufficient authority to establish, maintain, and develop a positive and conducive school climate for school progress. Thus, besides, the occurrence of climate change also affects the performance motivation and behavior of employees in schools towards achieving the stipulated targets.

The need to build an independent commitment individual school community, including teachers, in an attempt to eliminate the bureaucratic rigidity of thoughts and culture. This includes the practice of having to wait for the superiors' instructions by stimulating creative and innovative thinking (Mulyasa, 2013). Thus, teacher commitment is 
an attachment to duties and obligations that lead to responsive and innovative responsibilities and attitudes towards advancements in science and technology.

Based on the description it was established teacher's commitment as an attachment to the duties and obligations with the propensity to promote responsive and innovative responsibilities and attitudes, aimed at the development of science and technology. Furthermore, commitment demands the contribution of several elements, including the understanding of self and duties, as well as inner, outer strength, and the responsiveness to change. These elements provide responsibility for duties and obligations, which become an individual's commitment to ensure the proper performance of the task with full sincerity. Sion (2006) said that job satisfaction has a meaning as a picture of someone's happiness or positive feelings towards the job and work environment. A person's performance is influenced by the level of job satisfaction concerned. pleasure or displeasure feelings with job and work environment have a great influence on the work achievement. Teachers are required to have a feeling of liking the task assigned to him. So, teachers must have high commitment and job satisfaction.

The relationship between instructional leadership, organizational climate, and commitment of elementary teachers is enough to determine the level of job satisfaction. This fosters the growth in the interpersonal ability to properly conduct designated duties, which consequently increases their professional level. Also, good instructional leadership of principals, alongside a positive organizational environment, and a high level of teacher commitment tends to greatly contribute to job satisfaction.

The relationship between the principal's instructional leadership, organizational climate, and teacher's commitment to the job satisfaction of elementary teachers in Tapin Utara Subdistrict, Tapin District, which is the instructional leadership of the school principal, organizational climate, and teacher commitment are enough to determine the level of job satisfaction of a teacher so that if the commitment grows in the strong teacher to carry out their duties properly the teacher's professional level will also increase. Good principal instructional leadership, positive organizational climate, and high teacher commitment will contribute greatly to increasing teacher job satisfaction in SDN at Tapin Utara District Tapin Regency.

Based on this background, the current study aims to analyze the relationship arising between instructional leadership, organizational climate, teacher commitment to job satisfaction.

\section{Material and Methods}

This research uses a descriptive method with a quantitative approach. The population of this study encompassed all teachers in Tapin Utara Subdistrict, Tapin District, totaling 155 people, and the sample size of 92 , using a nonprobability sampling technique.

Data collection required the distributing of questionnaires in the form of a list of questions, which were addressed directly to several respondents. These include teachers, and it was centered on the job satisfaction obtained at the elementary school. Furthermore, the questionnaire was based on a Likert scale, with a scoring scale of 5 for strongly agree; 4 for agree; 3 for neutral; 2 for disagree; and 1 for strongly disagree. Furthermore, the results obtained were analyzed using path analysis techniques, with IBM SPSS 20.

Both stages involved the use of a quantitative approach through path analysis in testing the amount of contribution shown by the correlation coefficient between variables as follows: (1) Instructional Leadership (x) on job satisfaction (y); (2) Instructional Leadership $(\mathrm{x})$ towards the organizational climate $\left(\mathrm{z}_{1}\right)$; (3) Instructional Leadership $(\mathrm{x})$ toward teacher commitment $\left(\mathrm{z}_{2}\right)$; (4) Organizational climate $\left(\mathrm{z}_{1}\right)$ on job satisfaction (y); (5) Teacher commitment $\left(\mathrm{z}_{2}\right)$ for job satisfaction (y); (6) Instructional Leadership $(\mathrm{x})$ to job satisfaction $(\mathrm{y})$ through organizational climate $\left(\mathrm{z}_{1}\right)$; (7) Instructional Leadership $(\mathrm{x})$ to job satisfaction (y) through teacher commitment $\left(\mathrm{z}_{2}\right)$.

The path analysis model performed is demonstrated in Figure 1 below. 


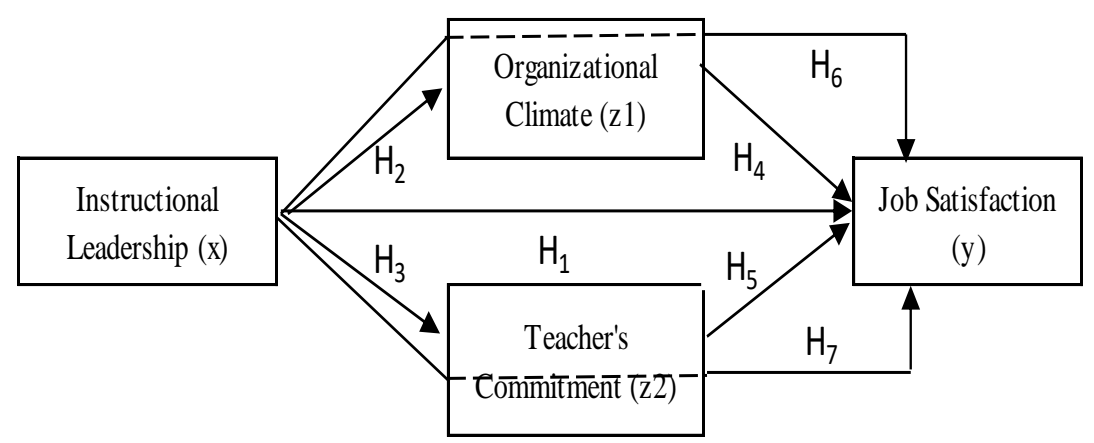

Figure 1. Path analysis

Table 1. Summary of decision on hypothesis $\mathrm{H}_{1}, \mathrm{H}_{2}, \mathrm{H}_{3}, \mathrm{H}_{4}$, and $\mathrm{H}_{5}$

\begin{tabular}{llcc}
\hline & Hypothesis & $\boldsymbol{\beta}$ & Decision \\
\hline $\mathrm{H}_{1}$ & $\begin{array}{c}\text { Relationship between the principal's instructional leader- } \\
\text { ship and teacher satisfaction }\end{array}$ & 0.404 & Accepted \\
\hline $\mathrm{H}_{2}$ & $\begin{array}{c}\text { Relationship of the principal's instructional leadership and } \\
\text { the organizational climate }\end{array}$ & 0.454 & Accepted \\
\hline $\mathrm{H}_{3}$ & $\begin{array}{c}\text { Relationship between the principal's instructional leader- } \\
\text { ship and teacher commitment }\end{array}$ & 0.408 & Accepted \\
\hline $\mathrm{H}_{4}$ & $\begin{array}{c}\text { Relationship between organizational climate and teacher } \\
\text { job satisfaction }\end{array}$ & 0.394 & Accepted \\
\hline $\mathrm{H}_{5}$ & $\begin{array}{c}\text { Relationship between teacher commitment and teacher job } \\
\text { satisfaction }\end{array}$ & 0.567 & Accepted \\
\hline
\end{tabular}

Table 2. Summary of Decision for Testing Hypothesis $\mathrm{H}_{6}$ and $\mathrm{H}_{7}$

\begin{tabular}{cllll}
\hline \multicolumn{2}{c}{ Hypothesis } & \multicolumn{2}{c}{$\begin{array}{c}\text { Coefficient of Decision } \\
\text { Correlation }\end{array}$} & \multirow{2}{*}{ Decision } \\
\cline { 3 - 3 } & \multicolumn{1}{c}{ Direct } & Indirect & \\
\hline $\mathrm{H}_{6}$ & $\begin{array}{l}\text { Principal's instructional leadership with teacher } \\
\text { job satisfaction through an organizational } \\
\text { climate }\end{array}$ & 0.719 & 0.583 & Accepted \\
\hline $\mathrm{H}_{7}$ & $\begin{array}{l}\text { Principal's instructional leadership with teacher } \\
\text { job satisfaction through teacher commitment }\end{array}$ & 0.231 & 0.635 & Accepted \\
\hline
\end{tabular}

\section{Results and Discussion}

This study discusses four variables that involve the Tapin Utara sub-district, Tapin District. Furthermore, using statistic descriptive, the mean score achieved was measures affiliated with the relationship of principal instructional leadership, organizational climate, and teacher commitment with teacher job satisfaction. Also, these were all considered to be in the high category, according to the three interval groups, encompassing the low (less than [mean - 1 standard deviation]), the moderate (mean 1 standard deviation sd mean +1 standard deviation), and high groups (more than [mean +1 standard deviation]).

Concerning the results of the descriptive statistical test, several considerations require further discussion. For example, the principal's leadership variable was $100 \%$, hence, it is included in the high category. This was following the report of Usman (2014). Also, 
effective instructional leadership contains three aspects, which include: numerous discussions with teachers, supporting the ongoing development of professionalism, and strengthening their reflection on the learning process.

The organizational climate in elementary schools was $100 \%$, hence included in the high category. This is in line with the statement of Davis \& Newstrom (2000) which expressed the concept as the human environment where employees perform designated tasks, thus possessing the capacity to influence everything in the organization.

The commitment of teachers was evaluated to be $95.65 \%$, hence it is included in the high category. This condition agrees with Mubarak (2019), with commitment being the responsibility for work and the obligation as a professional. Also, commitment is required as indicated in Law Number 14 of 2003, concerning Teachers and Lecturers, stipulating the need for four competencies: pedagogical; (2) professional; (3) personal; and (4) social.

Teacher job satisfaction in elementary schools has a score of $92.39 \%$, thus included in the high category. This condition agrees with Indrasari (2017) which explained its concept as an achievement on instances where there is no difference between desire and the perception of reality because the minimum threshold has been met. Conversely, it also shows the degree of expectations in line with fulfilling one's psychological contract, therefore indicating the propensity of a higher value for those receiving a balanced contribution in their relationship towards organizational benefits.

From the hypotheses, direct and indirect effects were concluded through intermediate variables between the independent on the dependent.

\section{Relationship of Instructional Leadership with Teacher Job Satisfaction}

The findings of this study stated that instructional leadership significantly influenced the job satisfaction of elementary school teachers in the Tapin Utara District.
Thus the hypothesis $\left(\mathrm{H}_{1}\right)$ was accepted, it was established that instructional leadership affects by up to 0.404 . This result indicating that the least satisfied teachers are those with most desires without achieving it. Besides, highly satisfied people demand a lot and also obtain it. Therefore, the principal's leadership role in the aspect of increasing teacher job satisfaction is enormous, considering that a good exhibition is expected to be to make a significant contribution to improving their job satisfaction.

In the observation of instructional leadership quality from the teacher's attitude towards work, it is not possible to separate high and low job satisfaction. Thus, the principals' main task is more focused on learning and administrative functions, as leadership is required inadequate capacity to attain school goals.

The results of this study are in line with the report of Kaihatu (2007), which stated that transformational' leadership significantly influences job satisfaction in high school teachers of Surabaya city. Another study in 2015 reported its effect on job satisfaction, thus, a principal's leadership role is organized by the school owners, to develop the educational staff. In line with the investigation conducted by Bayram and Dinc (2015) at Bosnia and Herzegovina (a transitional country), the economic situation was reported to be weak and the unemployment rate was very high. This positively relates to the results of the current study, regarding the nature of work and job satisfaction. Besides, the association also extends in the dimensions of transformational leadership, based on the operating conditions in Bosnia and Herzegovina, which demonstrated employers as very satisfied with specific goals in working places and like work.

\section{Relationship Between Instructional Leader- ship and Organizational Climate}

The findings indicated the presence of a relationship between the principal's instructional leadership and organizational climate, thus, the hypothesis $\left(\mathrm{H}_{2}\right)$ was accepted effects by up to 0.454 . This result, the 
relationship was established between principal instructional leadership and organizational climate, an increase in the instructional leadership variable, which means that an improvement dictates a better organizational climate. Based on the result, the positive influence to organization climate means the better instructional leadership, the better organization climate

Hadiyanto (2016) said the school environment can be able to cause changes in teacher behavior, which subsequently affects work performance. Therefore, principals play a vital role in creating a conducive work climate. This was following the previous report of Gardner (Usman, 2014), which explained leaders as people that become an example and significantly influence the behavior of followers through several feelings. Northfield asserted for school principals, the main character as educational leaders are the leader (as a teacher) who allows participants or members to participate in developing a personal understanding and encouraging conditions for practical reflection (Bush \& Coleman, 2012).

The leadership encompasses the ability to take initiative in social situations, in an attempt to create new forms and procedures, design and regulatory actions and consequently generate cooperation toward the achievement of goals. According to the Directorate of Education Personnel (2010), instructional leadership was described as a form that focuses or stresses on learning components to include in the curriculum, teaching and learning process, assessment (of learning outcomes), as well as teacher evaluation and development, service excellence in learning and building school communication.

Instructional leadership and linkages with the organizational climate lead were explained by Suharsaputra (2016) as a form of leadership that focuses on determining the vision, mission, and goals of a school. This also involves managing, organizing, and coordinating the curriculum, alongside improving the quality of, and matters relating to learning, as well as coordinating the study environment to be conducive enough to further strengthen the school culture.
The results of this study are in line with research by Hidayat (2013), which stated the enhanced propensity for leadership to influence organizational commitment. This means that increasing the competency and experience of the banking unit head in East Java consequently promotes the commitment of other staff. A similar study was conducted by Allen, Grisby and Peters in the small suburban school district of southeast Texas, which was based on the importance of transformational leadership as a contributing factor to school climate, instigated the rationality of including the practice of regularly evaluating a principal's characteristics. Furthermore, teachers tend to feel more positive about their school environment on instances where the leader values them as a partner in the program, not just as a staff member. Besides, leaders that demonstrate individualized considerations exhibit more confidence in the abilities of the workforce, subsequently influencing the school climate positively.

\section{Relationship Between Instructional Leader- ship and Teacher Commitment}

The findings of this study established that instructional leadership significantly influences the commitment of elementary school teachers in the Tapin Utara sub-district, hence the hypothesis $\left(\mathrm{H}_{3}\right)$ was accepted, has an effect by up to 0.408 . This result means the absence of difficulties and confusion during the work commitments of teachers. This is possible, based on the direction and guidance of principals in all learning administration and activities, therefore, promoting the capacity to maximally conduct teaching and learning activities. Furthermore, teachers tend to feel love for work, as seen in the mental reaction exhibited towards intense work, characterized by being full of pleasure and actively performing the designated duties as educators, followed by the display of high work commitments.

According to Sukmawati \& Herawan (2016), the concept of leadership that focuses on teaching-learning activities and teacher behavior in serving students emphasizes on efforts to improve commitment. This is attained through the act of inviting, 
encouraging, directing, and facilitation for performance development. Meanwhile, performing empowerment strategies enhances the tendency of excellence in delivering quality services, and also motivates teachers to develop professionalism.

Based on this evaluation, it is possible to say instructional leadership is a factor that is no less important in building commitment, thus, an effective principal ought to effectively conduct designated functions. This includes providing employees with the clarity and convenience to carry out respective duties and functions, as well as a sense of understanding, need in the workplace.

The results of this study are in line with the research of Othman and Saad (2017) in Malaysia, which reported the existence of a relationship between instructional leadership and the communication style of the principal. This was designated as a factor capable of affecting the commitment of teachers in the Daily National High School (SMK) in Kedah. Furthermore, teachers tend to show a higher level of commitment when directed by instructional leadership and the principal's communication style. This was in line with research by Damai, Effendi, and Sulaiman (2019) which stipulated the significant impact of the headmaster's style as a leader on teacher performance.

\section{Relationship Between Organizational Cli- mate and Teacher Job Satisfaction}

The findings of this study show that instructional leadership significantly influences the commitment of elementary school teachers in the Tapin Utara sub-district, thus, the hypothesis (H4) was accepted, has an 0.394. This result indicating that the organizational climate ought to be created in a manner where teachers feel comfortable in performing a designated task. This is because a good condition is expected to influence the increase in job satisfaction of teachers. Steer (Hadiyanto, 2016) adopted this concept, bearing in mind the relationship between organizational climate and job satisfaction, hence, it was concluded that the school atmosphere also determines the level of job satisfaction. Mukhlis reported of 5 (five) affiliated variables and their relationship with the organization, are: (1) usually, high turvoners in less satisfied employees (2) the enhanced propensity of absences; 3) an increased tendency for older employees to be more satisfied than the relatively young; (4) the level of work for those that occupy higher positions become more quickly satisfied than the lower levels and (5) the size of the organization related to employee coordination, communication, and participation. The results of research by Tadampali, Hadi, and Salam (2016) showed the enhanced propensity for an improved organizational climate to positively affect job satisfaction of employees at PT. Bank Sulselbar Makassar.

This study is in line with the report by Sahin (2011) which stated that teachers with graduate degrees evaluate principals' instructional leadership styles more positively. Also, the instructional pattern tends to have a positive impact on school and classroom culture, and consequently on student achievement, despite the differences in culture between the USA and Turkey.

\section{Relationship of Teacher's Commitment to Teacher Job Satisfaction}

The findings of this study indicate that teacher commitment significantly influences job satisfaction of elementary school teachers in the Tapin Utara sub-district, thus, the hypothesis $\left(\mathrm{H}_{5}\right)$ was accepted, affects 0.567 . Hence the teacher as a determinant from educational success in schools. Furthermore, the teacher's commitments are attention and concern for learning. Also, job satisfaction is important in schools. This is the one which is the major influence of implementation performance assessments. According to Reyes and Pounder (1990), Schools be classified as normative organizations with the incidence of high commitment and elevated job satisfaction.

The results of this study are also in line with the report by Aisyah's (2017), which attributed the low job satisfaction of employees to the symptom of the instability of an organization. Besides, the most extreme forms of dissatisfaction were expressed in the form of 
work strikes, defaulters, and taking a leave. Therefore, the current problems of various teachers continue to increase, although the low satisfaction is suspected to currently below, while the compensation received is minimal and unsuitable to meet the needs of self and family life. Furthermore, it is not appropriate for teachers to face this impact as it affects commitment, and vice versa, as a good level of fulfillment increases commitment (Aisyah, 2017). Based on the above job satisfaction is said to be a reflection of the teacher's commitment towards the designated task. A similar study by Tafqihan and Suryanto (2014), conducted on Mathematics teachers in public and Islamic Junior High Schools of Ponorogo Regency shows the influence of the teacher's professional commitment variable, which explains that job satisfaction leads to an enhancement of positive behaviors. This further promotes the ability to serve as an example to students, the school, and the community at large.

There is a positive relationship between a teachers' commitment to job satisfaction, which is in line with the study by Satria (2005), which reported the existence of a positive and very significant correlation between organizational commitment and job satisfaction among the employees of Universitas Muhammadiyah Surakarta, meaning that a higher responsibility to an organization promotes the propensity of employee job satisfaction and vice versa.

Relationship Between Instructional Leadership and Teacher Job Satisfaction Through Organizational Climate

The findings of this study indicate that instructional leadership significantly influences the commitment of elementary school teachers in the Tapin Utara sub-district, thus the hypothesis $\left(\mathrm{H}_{6}\right)$ was accepted, affects by up to 0.583 . this result indicating the positive impact of the principal's instructional leadership towards increasing employee job satisfaction. This is attainable through items in the context and the administration of learning and the related activities performed with teachers (creating a good climate). Thus, it is concluded that better leadership enhances the capacity to build a conducive environment, and better job satisfaction consequently.

The results are in line with the Usman report (2015), which showed the propensity for benefits of instructional leadership towards increasing satisfaction through periodic monitoring and evaluation, alongside ensuring continuous student learning outcomes. Furthermore, a similar research by Amri et al. (2017) reported that transformational leadership has a significantly positive effect on organizational citizenship behavior through the environment. Hence, it was proven that the atmosphere in the Directorate General of Population and Civil Registration of Mataram city is very pleasant.

\section{Relationship Between Instructional Leader- ship and Teacher Job Satisfaction Through Commitment}

The findings of this study state that instructional leadership significantly affects elementary school teacher commitment in the Tapin Utara sub-district, hence the hypothesis (H7) is accepted, affects by up to 0.635 . this result indicates that the propensity for the instructional leadership of principals to increase the employees' commitment to work, and subsequently the sense of enhanced satisfaction in conducting designated tasks. Furthermore, the effective, efficient, and professional conduction of leadership duties, functions, and responsibilities is followed by the promotion of commitment levels. Thus, a relationship is assumed to exist between the principal's instructional leadership and teacher job satisfaction through commitment.

This is study appropriate with the opinion from Aslamiah (2015), which states the relationship between job satisfaction and a person's attitude feelings towards a task. Hence, a minded individual tends to get job satisfaction positively, vice versa. Based on observation and emotional experience, a fulfilled teacher always has a work favorable assessment.

This is in line with the report by Luthans (2006), which stated that four out of the six factors that affect job satisfaction include: the nature of the work itself, compensation, and promotion opportunities, as their collective 
supervision is fulfilled only when the principal judiciously performs the task of an effective instructional leader as an indicator of job satisfaction. Herzberg's theory (Robbins and Judge, 2008) stated the tendency for hygiene factors to motivate a person to emerge from a state of dissatisfaction, including through human relations, rewards, environmental conditions, and other extrinsic factors. This is also following the concept where commitment affects job satisfaction, which develops from what is received both from the behavior of superiors and the nature of the awards received. Another study conducted by Pramudito and Yunianto (2009) stipulated the existence of an indirect effect of leadership on performance by mediating organizational commitment. Therefore, the effectiveness of efforts to improve performance is possibly enhanced through the creation of leadership following members' wishes, hence increasing commitment towards the organization. Furthermore, research by Hidayati (2014) shows transformational leadership through employee organizational commitment to employee performance confers a dominant influence than transactional leadership towards performance, through employee commitment.

\section{Conclusion and Recommendation}

Based on the results obtained in this study it can be concluded that there is a direct and indirect relationship between instructional leadership, organizational climate, teacher commitment, and job satisfaction. the principal's leadership is the basis for the achievement of job satisfaction of teachers and staff in the organization both directly and through the organizational climate created and the commitment of each teacher.

The following suggestions are, therefore, submitted to the following parties: (1) For principals, conducting the role of instructional leadership the principals' ability to maintain attitudes towards coworkers in the school ensures that job satisfaction is met for teachers and other employees; and (2) For teachers, a further increase in work commitment; and (3) Further research on teacher job satisfaction ought to be more in-depth, through the use of other variables with the propensity to confer an effect.

\section{Acknowledgment}

The authors are grateful to the principal, and elementary school teachers in the Tapin Timur sub-district, as well as the Education Office in Tapin District that helped immensely in the study outcome. The author also likes to appreciate Jk6em for providing direction, discussion, and advice in the preparation of this article.

\section{References}

Aisyah, S. (2017). Pengaruh kompensasi dan kepuasan kerja terhadap komitmen guru bidang Ekonomi SMA swasta Kota Pontianak. Pontianak: Program Magister Pendidikan Ekonomi FKIP Universitas Tanjung Pura.

Amran. (2015). Faktor penentu keberhasilan pengelolaan satuan pendidikan. Jurnal Manajer Pendidikan, 9(2), 185-196. Retrieved from http://ejournal.unib.ac.id/index.php/manajerpendidikan /article/viewFile/1113/922.

Amri, K., Abidin, Z., \& Nurmayanti, S. (2017). Pengaruh kepemimpinan transformasional terhadap organizational citizenship behavior dengan iklim organisasi sebagai variabel intervening (studi pada kantor DUKCAPIL Kota Mataram). Jurnal Magister Manajemen (JMM), 6(4), 1-13. doi:10.29303/jmm.v6i4.266

Ariyani, R. (2017). Kepemimpinan kepala sekolah dalam pengembangan profesionalisme guru. Jurnal Al-Afkar, 5(1). doi:10.28944/afkar.v5i1.135

Aslamiah. (2015). Kepuasan kerja guru dalam rangka meningkatkan efektivitas sekolah. Prosiding Seminar Nasional. 1, pp. 1-8. Banjarmasin: PS2DMP. Retrieved from http://rumahjurnal.net

Asniwati. (2015). Pengembangan manajemen mutu terpadu untuk penyelenggaraan pendidikan pada Sekolah Dasar Di Kota Banjarmasin. Seminar Nasional (pp. 9-16). Banjarmasin: PS2DMP. Retrieved from http://rumahjurnal.net

Bayram, H., \& Dinc, S. (2015). Role transformational leadership on employee's job satisfaction: the case of private universities in Bosnia and Herzegovina. Journal of European Reseacher, 93(4), 270-282. doi:10.13187/er.2015.93.270

Bush, T., \& Coleman, M. (2012). Manajemen mutu kepemimpinan pendidikan. Jogjakarta: DIVA Press.

Damai, S., Effendi, R., \& Sulaiman. (2019). The teacher achievement motivation as an intervening variabel in 
relationship between teacher's profesionalism, principal's leadership and teacher's performance of State High School in Banjarmasin City. Journal of K6, Education and Management, 2(1), 23-35. Retrieved from dev.j-k6em.org

Davis, K., \& Newstrom, J. W. (2000). Perilaku dalam organisasi, Edisi Ketujuh, Jilid I. Jakarta: Erlangga.

Direktorat Tenaga Kependidikan. (2010). Kepemimpinan pembelajaran: materi penguatan kemampuan kepala sekolah. Jakarta: Kementrian Pendidikan Nasional.

Hadiyanto. (2016). Teori dan pengembangan iklim kelas \& iklim sekolah. Jakarta: Kencana.

Hidayat, N. (2013). Pengaruh kepemimpinan terhadap komunikasi, kepuasan kerja dan komitmen organisasi pada industri perbankan. Jurnal Makara Seri Sosial Humaniora, 17(1), 19-32. doi:10.7454/mssh.v17i1.1799

Hidayati, S. N. (2014). Pengaruh kepemimpinan transformasional dan transaksional terhadap kinerja karyawan dengan komitmen organisasi sebagai "intervening variable". Jurnal Maksipreneur, III(2), $117-$ 132. doi:10.30588/jmp.v3i2.158

Indrasari, M. (2017). Kepuasan kerja dan kinerja karyawan Yogyakarta: Indomedia Pustaka.

Kaihatu, T. S. (2007). Kepemimpinan transformasional dan pengaruhnya terhadap kepuasan atas kualitas kehidupan kerja komitmen organisasi dan perilaku ekstra peran: studi pada guru-guru SMU di Kota Surabaya. Jurnal Manajemen dan Kewirausahaan. doi:10.9744/jmk.9.1.pp.\%204961

Luthans, F. (2006). Perilaku Organisasi Edisi Sepuluh. Yogyakarta: Andi.

Mataputun, Y. (2018). Kepemimpinan kepala sekolah. Ponorogo: Uwais Inspirasi Indonesia.

Mohtar, I. (2019). Hubungan motivasi kerja dan pengalaman kerja dengan kinerja guru madrasah. Ponorogo: Uwais Inspirasi Indonesia.

Mubarak, Z. (2019). Problematika pendidikan kita: masalahmasalah fkatual dari guru, desain sekolah dan dampaknya. Depok: Ganding Pustaka Depok.

Mulyasa, E. (2013). Menjadi guru professional. Bandung: PT. Remaja Rosdakarya.

Nasional, D. P. (2005). Undang-Undang Nomor 14 Tahun 2005 Tentang Guru dan Dosen. Jakarta: Departemen Pendidikan Nasional.

Othman, F., \& Saad, N. (2017). Kepemimpinan instruksional dan gaya komunikasi pengetua dengan komitmen guru Sekolah Menengah Kebangsaan (SMK) Harian di Negeri Kedah. International Conference of Scholarship of Teaching and Learning (pp. 83-91). Malaysia: School of Education and Modern Language, Universiti Utara Malaysia. Retrieved from www.seml.uum.edu/my.
Pace, R. W., \& Faulos, D. F. (2006). Komunikasi organisasi: strategi meningkatkan kinerja perusahaan. Bandung: Remaja Rosdakarya.

Pramudito, L., \& Yunianto, A. (2009). Pengaruh kepemimpinan dan motivasi terhadap kinerja dengan komitmen organisasional sebagai mediasi (studi pada perangkat se Kecamatan Batang Kabupaten Batang). Jurnal TEMA, 6(1), 1-18. Retrieved from www.akademia.edu

Reyes, P., \& Pounder, D. G. (1990). Teacher commitmen, job satisfaction, and school value orientation: A study public and private. Madison: University of Wisconsin.

Robbins, S. P., \& Judge, T. A. (2008). Perilaku organisasi Edisi 12. Jakarta: Salemba Empat.

Sagala, S. (2013). Etika \& moralitas pendidikan: peluang dan tantangan. Jakarta: Kencana.

Sahin, S. (2011). Instructional leadership in Turkey And The United State: Teachers' Perspective. Journal of Problems of Education in the 21st Century (PMC), 122-137. Retrieved from www.scientiasocialis.lt

Satria R.A, R. Y. (2005). Hubungan antara komitmen organisasi dan iklim organisasi dengan kepuasan kerja karyawan Universitas Muhammadiyah Surakarta. Benefit Jurnal Manajemen dan Bisnis, 120-128. doi:10.23917/benefit.v9i2.1216

Sion, H. (2006, Februari). Hubungan antara komitmen dan kepuasan kerja guru dengan performa mengajar guru SDN Di Daerah Terpencil. Jurnal Ilmu Pendidikan, 13(1), 51-55. doi:10.17977/jip.v13i1.63

Suharsaputra, U. (2016). Kepemimpinan inovasi pendidikan. Bandung: Refika Aditama.

Sukmawati, C., \& Herawan, E. (2016). Kepemimpinan instruksional kepala sekolah, komitmen guru dan mutu kinerja mengajar guru. Jurnal Administrasi Pendidikan, XXIII (2), 68-88. Retrieved from ejournal.upi.edu/index.php/JAPSPs

Tadampali, A. C., Hadi, A., \& Salam, R. (2016). Pengaruh iklim organisasi terhadap turnover intention melalui kepuasan kerja sebagai variabel intervening pada PT Bank Sulselbar. Jurnal Administrasi Publik, 6(2), 35-46. doi:10.26858/jiap.v6i2.2479

Tafqihan, Z., \& Suryanto. (2014). Pengaruh kompetensi guru terhadap komitmen profesional dan dampaknya pada kinerja serta kepuasan kerja guru Matematika SMP dan MTS. Jurnal Riset Pendidikan Matematika, 284-296. doi:10.21831/jrpm.v1i2.2682

Usman, H. (2014). Manajemen teori, praktik, dan riset pendidikan Edisi 4. Jakarta: PT. Bumi Aksara.

Wahyuningrum, M. M. (2015). Profesional kepala sekolah dalam menciptakan iklim kondusif di sekolahnya. Jurnal Manajemen Pendidikan UNY. Retrieved from 
https://media.neliti.com/media/publications/112561-

ID-profesionalisasi-kepala-sekolah-dalam-me.pdf 